\title{
An Assessment of the Relationship between Human Trafficking and Poverty in Nigeria
}

\author{
${ }^{1}$ Dr. Musa Abdullahi, ${ }^{2}$ M.A. Deribe, ${ }^{3}$ Sani Mustapha Kura \\ ${ }^{I}$ University of Maiduguri, Faculty of Social Sciences, Department of Sociology \& anthropology, Borno State, \\ Nigeria. \\ ${ }^{2}$ University of Maiduguri, Faculty of Law, Department of Private Law, Borno State, Nigeria. \\ ${ }^{3}$ Ramat Polytechnic,Maiduguri, Department of Social Services, Borno State, Nigeria.
}

\begin{abstract}
Human trafficking is an extreme human rights violation that impacts all populations across the globe and is characterized by force, fraud, and coercion intended for exploitation Research indicates that trafficked persons are typically poor, have few job prospects, limited access to education and may come from rural areas, depending on the country of origin. Although existing research easily identifies the vital role of economics in human trafficking, it has failed to probe the complex relationship between poverty, discrimination, and other socio-cultural factors such as minority status. It is against this backdrop that this paper intends to evaluate the relationship between human trafficking and poverty in Nigeria.
\end{abstract}

\section{Introduction}

Human trafficking is a matter of serious concern to local, National and international authorities, It is a form of business venture that dehumanize humanity in itself (W.H.O, 2002). A situation there humans turn follow humans into commodity and a product.

Human Trafficking is defined by the international protocol to prevent, suppress and punish trafficking in persons especially women and children as, the recruitment, transportation, transfer, harboring or receipt of persons: by the threat or use of Kidnapping force, fraud, deception or coercion, or by the giving or receiving of unlawful payments or benefits to achieve the consent of a person having control over another person, and for the purpose of several exploitation or forced labour.

Human trafficking is an extreme human rights violation that impacts all populations across the globe and is characterized by force, fraud, and coercion intended for exploitation (Palermo Protocol 2000). Currently, human trafficking research is particularly limited by non-standard terminology and a clandestine research population. While estimates of the number of trafficked persons vary widely and are notoriously unsubstantiated, we can still arrive at some conclusions regarding the overall number of trafficked persons. One low estimate suggests that in 2005, at least 2.4 million people had been trafficked into forced labor situations and approximately 12.3 million people were victims of forced labor (International Labor Organization 2005). In addition to compiling comprehensive data on the number of trafficked persons, researchers and policymakers must identify who is trafficked. Basic quantitative data on the raw numbers of trafficked persons is not enough; qualitative data is also required in order to combat this human rights violation. That is, what are the characteristics of trafficked persons; what do they have in common; and do those commonalities contribute to exploitation?

Research indicates that trafficked persons are typically poor, have few job prospects, limited access to education and may come from rural areas, depending on the country of origin (Omelaniuk 2005). As a result of these disadvantages, they are often compelled to migrate within or outside of the country for better economic opportunities (Laczko and Danailova-Trainor 2009). Thus, trafficked persons may willingly travel with an "employer" based on the promise of work as a waitress, farm worker, domestic worker, or in other industries. However, upon arriving at their destination, they may be refused wages or may be forced into another job entirely. In other cases, the individuals received an advance on their salary and are then told they must work for free to repay this debt, which is commonly known as debt bondage (Bedoya et al. 2009). Another common scenario is that of children sold by their parents, or of individuals (primarily women and girls) who were kidnapped or tricked by a boyfriend or family member, then sold to traffickers (e.g., Simkhada 2008). One of the underlying themes running through each of these scenarios is the desire for economic prosperity. Although existing research easily identifies the vital role of economics in human trafficking, it has failed to probe the complex relationship between poverty, discrimination, and other socio-cultural factors such as minority status. Consequently, there is a distinct lack of research relating to traditionally disadvantaged groups and systemic discrimination within the body of human trafficking literature.

One potentially significant, but often overlooked, criterion in anti-trafficking research is poverty. Poverty is not measured in terms of how much money an individual has it or how many times does he eat in a day. Most 
often, people associate poverty with extreme low level of income. Poverty can be seen manifestation of a state of deprivation of basic requirement for quality of life this may include deprivation of food shelter, life drinking water, employment health education and clothing among others.

When a person is deprived of those essential services and goods, he is thus poor and poverty ridden. He may thus be at risk of engaging in available means of containment of life including Human Trafficking, child abuse, robbery, drug traffic and host of other social problems.

Government over the years has spent billions of Naira and established agencies and units to enable it overcome the multiracial social problems of poverty human traffic, and child abuse. But despite governments' concern investment and the huge financial expenditure the issue of poverty trafficking and other social problems in our poverty still remains a matter of serious concern to the general public.

\section{What are the roots causes of trafficking?}

The root causes of trafficking are various and often differ from one country to another. Trafficking is a complex phenomenon that is often driven or influenced by social, economic, cultural and other factors. Many of these factors are specific to individual trafficking patterns and to the States in which they occur. There are, however, many factors that tend to be common to trafficking in general or found in a wide range of different regions, patterns or cases. One such factor is that the desire of potential victims to migrate is exploited by offenders to recruit and gain initial control or cooperation, only to be replaced by more coercive measures once the victims have been moved to another State or region of the country, which may not always be the one to which they had intended to migrate.

Some of the common factors are local conditions that make populations want to migrate in search of better conditions: poverty, oppression, lack of human rights and lack of social or economic opportunity, dangers from conflict or instability and similar conditions. Political instability, militarism, civil unrest, internal armed conflict and natural disasters may result in an increase in trafficking. The destabilization and displacement of populations increase their vulnerability to exploitation and abuse through trafficking and forced labour. War and civil strife may lead to massive displacements of populations, leaving orphans and street children extremely vulnerable to trafficking.

These factors tend to exert pressures on victims that "push" them into migration and hence into the control of traffickers, but other factors that tend to "pull" potential victims can also be significant. Poverty and wealth are relative concepts which lead to both migration and trafficking patterns in which victims move from conditions of extreme poverty to conditions of less-extreme poverty. In that context, the rapid expansion of broadcast and telecommunication media, including the Internet, across the developing world may have increased the desire to migrate to developed countries and, with it, the vulnerability of would-be migrants to traffickers.

The practice of entrusting poor children to more affluent friends or relatives may create vulnerability. Some parents sell their children, not just for the money, but also in the hope that their children will escape a situation of chronic poverty and move to a place where they will have a better life and more opportunities.

In some States, social or cultural practices also contribute to trafficking. For example, the devaluation of women and girls in a society makes them disproportionately vulnerable to trafficking. Added to these factors are the issues of porous borders, corrupt Government officials, the involvement of international organized criminal groups or networks and limited capacity of or commitment by immigration and law enforcement officers to control borders.

Lack of adequate legislation and of political will and commitment to enforce existing legislation or mandates are other factors that facilitate trafficking in persons. In response to the above root causes, most prevention strategies fall within one of the following categories:

- Reducing the vulnerability of potential victims through social and economic development

- Discouraging the demand for the services of trafficked persons

Public education

- Border control

- Preventing the corruption of public officials

\section{Poverty}

Poverty is a condition of incapacitation of human being to experience a moderate livelihood, his inability have access to basic essentials of life and the uncertainly of what tomorrow has for him. The World Development Indicators (2004) explained that poverty is the deprivation of common necessities of life such as food, clothing, shelter and safe drinking water and may also include the deprivation of opportunities to learn, to obtain a better employment to stay out of poverty. The Bank Report (2005) explained that poverty is the inability of the individual to attain minimum standard of living.

Within the context of the Nigeria society, most of its population fit into the World Bank Report (2005) and World Development Indicators (2004) operationalization of poverty. Some scholars such as Ajakiye and 
Olomola (1999) Ozigbo (2001) and Englama, (1997) argued that poverty indicators go beyond an individual income or consumption pattern. Purchasing power, physical health and education play significant impact on individual life inadequate access to the attainment of such variation will make the individual to wallow in lovo-economic, political and environmental deprivation. The implication for such deprivation is that the individual may not have moderate shelter and health are, how job and educational opportunities, poor and unbalanced deity food, infant mortality and low life expectancy. Our local government areas today are facing similar conditions. Most of it population hardly eat two meals in a day and those who can afford to eat two or one equal male a day, may not have the required nutritional balanced food for healthy growth. Health care is very inadequate while public school fails to provide minimum education to it population in their locality. Flood and fire outbreak has left thousands homeless as a result of poor housing condition and complete absence of drainage systems majority of our population are living in poverty.

\section{Human Trafficking: A global problem}

Globally, human trafficking has assumed alarming dimensions in the recent past, and it is now considered second only to the trafficking in drugs and guns.

- In 2005 the international Labour Organization (ILO) estimated that human trafficking had annual profits of approximately US $\$ 31.6$ billion.

- The Organization for Economic Co-operation and Development says that human trafficking is the third largest grossing sector of organized crime after drugs and arms.

- United Nations Office on Drugs and Crime's Global Report on Trafficking in Person (2009) reveals that the majority of trafficking victims identified by states are women and children who make up $88 \%$ of all victims ( $66 \%$ of victims are women, $13 \%$ girls, $9 \%$ boys, and $12 \%$ men).

- The US Department of State's 2008 Trafficking in Persons Report estimated that there are at least 800,000 people trafficked across borders annually: The majority being women trafficked for commercial sexual exploitation. Approximately 80 percent of trans-national victims are women and girls and 20 per cent are men and boys. This does not account for the estimated millions who are trafficked within their own countries.

- UNICEF estimates that more than one third of victims of human trafficking come from pass through or end up in South-East Asia.

- In their 2002 report, the ILO states 1.2 Million children are trafficked every year for labour and sexual exploitation.

- UNICEF estimates that 5.7 million children are trapped in forced and bonded labour and that children represent half of forced labours.

- In the 2004 Give 2Asia Laos Safe Shelter proposal if is stated that due to weak social re-integration and other services, the number of girls who are re-trafficked continues to increase. At the time of the proposal the re-trafficking rate was $15-20$ per cent.

\section{Fighting Poverty and Human Trafficking}

One of the goals of Millennium development goals (MDG) is to achieve universal extreme poverty and hunger eradication by the year 2015. The Nigeria government has established MDG unit under the presidency and directed state and local government to establish to enable it achieve the goals. Since its inception, billions of naira has been expanded from federal to state levels, other directory of poverty eradication programme was also established from federal to local government levels and huge financial obligation is expanded. Many Non-governmental organizations (NGO'S) also collaborate with state and federal government in its effort to eradicate governments in its effort to eradicate poverty and human trafficking.

The national agency for the prohibition of traffic in persons and other related matters (NAPTIP) was also established. The establishment of NAPTIP is a clear demonstration of the political will of the federal government of Nigeria to tackle the serious scourge of trafficking in persons. It further demonstrates the country's commitment to her international delegations as a signatory to the transnational organized Crime Convention and trafficking in person's. The NGO's, state government, Local governments and other stakeholders have over the year been collaborating in one way or the other to achieve the desired objective of eradicating poverty and conducts that subject human beings to all forms of exploitation.

\section{Obstacles}

With the huge financial commitment from the federal Government down to the Local council and other stake holders. The problem of human trafficking and poverty still remains a matter of serious concern to all and sundry. Most often there is an outcry among Government agencies of a foul play or complete negligence or misdirection of policies and initiatives in achieving the goal of controlling human trafficking or poverty eradication. 
Most often Government allocations and counterpart funding becomes very difficult for individuals or Local Government Authorities to access or meet up their obligation in executing any of the programmes and as a result of these laudable Government initiatives remains unimplemented and all efforts and initiatives becomes a waste.

There is also high level of corruption, parochialism and embezzlement among public office holders which accounts for the poor or complete lack of implementation of such laudable programmes. Political party patronage and differences also contributes to the partial or selective implementation of such programmes. Non-challant attitudes and lack of commitment and concern from the parts of traditional leaders, religious leaders and other stake holders adds to the multiplicity of the problems affecting the realization of the laudable objectives of NAPEP, NAPTIP, MDG and other related agencies that were established to eradicate poverty or human trafficking.

\section{The Need for Collaborative Approach}

It is now evident that the federal government, the state government, local councils and NGO's have established various units and agencies for the benefit of the entire society. Corruption, poor governance, lack of commitment, ignorance is some of the major obstacles. Local Government Chairmen as a matter of responsibility and oath of office should live up to expectations; they should collaborate with both the traditional and religious leaders in disseminating government policies and programmes objectively.

Agencies such as NAPTIP should be seen as partners in progress and co-operate in the execution of their programmes.

The agencies, NGO's, Local government council, traditional leaders, religious leaders and other state holders should see their position as a call to the service of humanity. Each and every one of them have a unique and specific role in the larger society but none can in isolation be useful to the general society or to the citizens under their domain until they collaborate, relate, respect and carry each other along in their domain of administration.

\section{Conclusion}

Poverty, human trafficking, child abuse and other related social problems is a serious global and National Problem. There is the need to co-operate and collaborate with all agencies found in every local government and assist where necessary.

Counter funding and information's pertaining the local government areas should be seriously pursued and be executed. Government officials and persons with responsibility should try and enhance their relationship with one another, improve in the management of their resources be transparently honest in their obligations and embrace dialogue in matter affecting their community.

People in authority should ensure fair distribution of resources such as those of poverty alleviation programmes to the citizens in their locality irrespective of religious affiliation, ethnicity and political party membership. They should also act as outlets of information and suggestions to organizations such as NAPTIP and others to enable them carry out their obligations.

\section{References}

[1]. Ajakiye and Olomola (1999) Enhancing Access to Grazing Resources as poverty Alleviation Strategy in the Arid Zone of Nigeria. Nigerian Economic society conference.

[2]. Englama, A. (1997) Measurement Issues in Poverty GBN Economic and Financial Review Vol.33 No.3.

[3]. Ozigbo N.C. (2001) Rural Poverty in Nigeria: Policy Implementation and Development. International Journal of Economic and Development Issues Vol. 1 No. 1

[4]. Ali, Yousef. 2006. "Stateless and Citizenship Rights in the Middle East: the Case of Kuwait." DOMES: Digest of Middle East Studies 15 (1):62-76.

[5]. Bales, Kevin. 2005. Understanding Global Slavery: A Reader: University of California Press.

[6]. Bastia, Tanja. 2006. "Stolen Lives or Lack of Rights? Gender, Migration and Trafficking." Labor, Capital and Society. 39 (2):20-47.

[7]. Beeks, Karen and Delila Amir (eds.). 2006. Trafficking and the Global Sex Industry. Lexington Books

[8]. Betz, Diana. 2009. Human Trafficking in Southeast Asia: Causes and Policy Implications, National Security Studies, Naval Postgraduate School, Monterey.

[9]. Goodey, Jo. 2008. "Human Trafficking: Sketchy Data and Policy Responses." Criminology and Criminal Justice 8 (4):421-442.

[10]. Grover, Sonja. 2007. "Children as Chattel of the State: Deconstructing the Concept of Sex Trafficking." International Journal of Human Rights 11 (3):293-306.

[11]. Goodey, Jo. 2008. "Human Trafficking: Sketchy Data and Policy Responses." Criminology and Criminal Justice 8 (4):421-442. 